Norvia: Analisis Konteks dan Wujud Ekologi Dindang Anak Unggat-Unggat Apung...

\title{
ANALISIS KONTEKS DAN WUJUD EKOLOGI DINDANG ANAK UNGGAT-UNGGAT APUNG ETNIK BANJAR KALIMANTAN SELATAN
}

\author{
Analysis of Context and Form of Ecology Children's Song Unggat-Unggat Apung Banjar \\ Ethnic South Borneo
}

\author{
Norvia \\ Universitas Lambung Mangkurat \\ Jalan Brigjen H. Hasan Basri, Banjarmasin \\ Pos-el: norviahanafi89@gmail.com
}

Naskah masuk: 2 Mei 2020; disetujui: 8 Juni 2020; revisi akhir: 22 Desember 2020

\begin{abstract}
Abstrak
Dindang (nyanyian atau lagu) Unggat-Unggat Apung etnik Banjar adalah dindang yang mengiringi sebuah permainan tradisional anak-anak yang berfungsi sebagai hiburan di waktu berkumpul orang tua dengan anak-anaknya di rumah. Sastra lisan khususnya dindang anak Unggat-Unggat Apung etnik Banjar merupakan dindang yang mulai kehilangan penuturnya. Hal ini disebabkan minimnya pelestarian dindang ini dalam bentuk dokumentasi tertulis, serta sudah tidak dikenalnya dindang ini di kalangan anak-anak etnik Banjar. Dindang sebagai salah satu bagian dari representasi kehidupan manusia seringkali memuat unsur budaya dan lingkungan manusia. Adanya penuangan unsur ekologi dalam sastra lisan khususnya dindang anak Unggat-Unggat Apung etnik Banjar semakin memperkuat adanya hubungan yang erat antara etnik Banjar dengan alam. Metode deskriptif kualitatif yang digunakan dalam penelitian ini akan memberikan gambaran dalam bentuk kata-kata dan gambar yang mengacu pada tujuan penelitian. Adapun hasil dari penelitian menunjukkan bahwa dari 33 larik dindang anak Unggat-Unggat Apung etnik Banjar ditemukan unsur ekologi flora 3 kata, unsur ekologi fauna $4 \mathrm{kata}$, dan unsur ekologi budaya yang tergolong peralatan dan perlengkapan hidup etnik Banjar terdiri atas 4 kata. Kajian ekologi sastra dalam penelitian ini diterapkan sebagai upaya menggali hubungan antara sastra dan ekologi etnik Banjar sebagaimana tertuang dalam dindang anak Unggat-Unggat Apung etnik Banjar.
\end{abstract}

Kata kunci: analisis konteks, wujud ekologi, dindang anak, etnik Banjar

\begin{abstract}
Dindang (song) Unggat-Unggat Apung of the Banjar ethnic group is a song that accompany a traditional children's game that functions as entertainment when parents gather with their children at home. Oral literature, especially the Dindang children of Banjar ethnics, Banjar ethnic is a song that has lost its speakers, this is due to the lack of preservation of this song in the form of written documentation, and this song is unknown among the Banjar ethnic children. Dindang as one part of the representation of human life often includes elements of human culture and environment. The existence of the pouring of ecological elements in oral literature, especially the existence of a close relationship between ethnic Banjar with its nature which is reflected in the song. The qualitative descriptive method used in this study will provide an overview in the form of words and images that refer to the purpose of the study. The results of the study found that from 33 lines of Dindang Unggat-Unggit Apung, found three ecological elements of flora, four ecological elements of fauna, and cultural ecological elements belonging to Banjar ethnic equipment and life equipment consisting of 4 words. The study of literary ecology in this study was applied as an effort to explore the relationship between literature and ecology of the Banjar ethnicity as set in the song of Dindang UnggatUnggit Apung.
\end{abstract}

Keywords: context analysis, form of ecology, children's song, Banjar ethnic 


\section{Pendahuluan}

Dindang anak (lagu anak) adalah salah satu jenis sastra lisan etnik Banjar yang sampai saat ini masih diwariskan secara turun-temurun dari generasi ke generasi etnik Banjar. Sebagaimana sastra lisan pada umumnya yang pewarisannya dilakukan dari mulut ke mulut, dindang anak ini cenderung minim dokumentasi tertulis sehingga perlu adanya penelitian sastra lisan yang lebih mendalam. Selain itu dindang anak memiliki fungsi tersendiri dalam lingkungan etnik Banjar misalnya sebagai media untuk menghibur si anak dengan menyampaikan doa-doa, nasihat, nilai-nilai moral, doktrin agama atau ajaran yang memberi efek manfaat bagi si anak yang mendengarnya.

Pembahasan tentang sastra lisan dan kajian ekologi sastra terhadap sastra lisan telah dilakukan dalam beberapa penelitian di antaranya, penelitian lagu menidurkan anak masyarakat Banjar (Adeliani, 2015) dalam jurnal AL-Banjari yang berjudul "Lagu Menidurkan Anak pada Masyarakat Banjar Kajian Bentuk, Makna, dan Fungsi", penelitian nyanyian Iusi oleh (Tawaulu, 2017) yang berjudul "Analisis Konteks, dan Proses Penciptaan Nyanyian Lusi Negeri Dulak Kecamatan Pulau Gorom Kabupaten Seram Bagian Timur" dalam jurnal Riksa Bahasa Volume 3 (2017), dan penelitian yang dilakukan oleh (Lembah, n.d.) dalam jurnal Bahasantodea, Volume 5 (2017) yang berjudul "Sastra Lisan di Kecamatan Dondo Kabupaten Tolitoli (Kajian Ekokritik)". Dalam jurnal-jurnal tersebut dipaparkan betapa eratnya sastra lisan dengan budaya masyarakat setempat yang diilhami oleh ekologi yang ada sehingga tercipta sebuah karya sastra, baik lisan maupun tulis.

Bascom mengasumsikan bahwa sastra lisan mempunyai empat fungsi, yaitu: a. sebagai sebuah bentuk hiburan, b. sebagai alat pengesahan pranata-pranata lembagalembaga, c. sebagai alat pendidikan anak, d. sebagai alat pemaksa dan pengawas agar norma-norma masyarakat akan dipatuhi anggota kolektifnya. Karya sastra baik lisan maupun tulisan dapat berfungsi dan digunakan sebagai media proyeksi pencerahan bagi manusia (Sudikan, 2015).
Finnegan dalam (Pudentia, 2008) mengasumsikan bahwa secara global sastra lisan dapat dibedakan atas sastra atau tradisi tertulis dan ini berarti berbeda dengan sastra tulis, penyebaran, komposisi, maupun pertunjukkannya dilakukan dari mulut ke telinga, dan bukan melalui kata- kata yang tertulis atau tercetak.

Menurut (Salleh, 1995) sastra lisan merupakan cabang besar dari kebudayaan lisan. Sastra lisan merujuk pada suatu cara berpikir secara lisan dengan logika dan sistem penyampaian informasi tersendiri. Budaya lisan yang dimaksud berupa tradisi lisan. Puisi rakyat, mantra, pantun, gurindam, dan nyanyian rakyat.

Brunvand (Danandjaja, 2007) mengungkapkan nyanyian rakyat terbagi atas dua jenis, yaitu:

1) Nyanyian rakyat yang tidak sesungguhnya

Dasar pembagian nyanyian ini didasarkan ada tidaknya lirik pada sebuah nyanyian (a) nyanyian rakyat tanpa katakata (worldess folksong), yakni suara yang dikeluarkan hanya meniru suara biola. Nyanyian jenis ini bisa digunakan untuk mengiringi suatu tarian rakyat. Jenis nyanyian yang menirukan suara biola itu disebut chin music atau didling. Nyanyian yang digunakan untuk mengiringi tarian Kecak di Bali termasuk dalam jenis nyanyian ini. (b) Nyanyian rakyat yang lariknya lebih menonjol dari pada iramanya (near song). Nyanyian rakyat di Indonesia yang tergolong jenis nyanyian ini adalah seruan yang digunakan oleh penjaja makanan ketika berkeliling kampung.

2) Nyanyian rakyat yang sesungguhnya

Yang termasuk dalam nyanyian ini adalah (a) Nyanyian rakyat yang berfungsi (fungsional song). Nyanyian rakyat yang berfungsi adalah nyanyian rakyat yang kata- kata atau lagunya memegang peranan yang sama pentingnya. Disebut berfungsi karena baik lirik maupun lagunya cocok dengan irama dan aktiviitas khusus dalam kehidupan manusia. Jenis nyanyian ini selanjutnya dibagi lagi menjadi tiga subkategori, yakni (1) nyanyian kelonan ( $/ u l l a b y)$, yakni nyanyian yang mempunyai lagu dan irama yang halus, tenang, berulang-ulang, dan ditambah dengan 
kata-kata kasih sayang yang dapat membangkitkan rasa santai, sejahtera, dan akhirnya menimbulkan rasa kantuk bagi anak-anak yang mendengarnya. Contohnya nyanyian "Nina Bobok". (2) nyanyian kerja (work song), yakni nyanyian yang mempunyai irama dan katakata yang bersifat menggugah semangat dan menimbulkan rasa gairah untuk bekerja. (b) Nyanyian-nyanyian daerah dari orang yang mempunyai mata pencaharian tertentu. Nyanyian rakyat ini beredar di antara para nelayan, petani, pengembala, tukang kayu, dan sebagainya. (c) Nyanyian rakyat bersifat berkisah (narrative song). Nyanyian rakyat yang bersifat berkisah adalah nyanyian yang menceritakan suatu kisah. Nyanyian yang termasuk kategori ini adalah balada (ballad) dan epos (epic).

Dindang anak "Unggat- Unggat Apung" dikelompokkan sebagai nyanyian rakyat sesungguhnya yang bersifat berkisah (narrative song) karena isi yang terkandung di dalamnya merupakan sebuah rangkaian cerita tentang seseorang yang bernama Indu Diyang yang bernada lucu sehingga dapat menyebabkan gelak tawa anak. Berbeda dengan nyanyian maayun anak yang membuat anak tertidur, nyanyian ini malah sebaliknya membuat anak tertawa terbahak-bahak. Dindang anak ini juga dibarengi dengan gerakan khas saat menyanyikannya. Gerakan dengan posisi telentang, lutut diangkat, kemudian si anak duduk di atas kaki, dengan gerakan kaki ke atas ke bawah tubuh si anak dibawa turun naik sambil melantunkan dindang Unggat-Unggat Apung. Oleh sebab itu, dindang ini dapat pula dikategorikan sebagai dindang permainan anak-anak.

Dindang ini hidup dan berkembang di kalangan etnik Banjar, namun eksistensi sastra lisan dindang anak Unggat-Unggat Apung sudah mulai kehilangan penuturnya. Hampir sebagian besar etnik Banjar tidak hafal dengan lirik dindang ini atau bahkan sama sekali tidak pernah mendengar dindang ini. Menurut tuturan informan (Saniah, 50 tahun), dindang UnggatUnggat Apung merupakan dindang yang sering dilantunkan oleh orang tua beliau dulu saat bermain dengan anak- anaknya. Selain bakisah (mendongeng), orang tua beliau sering kali bermain Unggat-Unggat Apung dengan beliau dan adik- adik beliau semasa kecil.

Jika dikaji dari pilihan kata dalam dindang anak Unggat-Unggat Apung terdapatnya kata kuyuk jelas menerangkan sastra lisan ini berasal dari daerah hulu yang merupakan penutur Bahasa Banjar Hulu bukan bahasa Banjar Kuala. Hal ini disebabkan kata kuyuk untuk menyebut anjing tidak digunakan oleh pengguna bahasa Banjar Kuala yang umumnya menggunakan sebutan adupan (hadupan).

Dindang anak Unggat-Unggat Apung ini menggunakan Bahasa Banjar yang berakar dari bahasa Melayu dan memiliki dua dialek besar, yaitu bahasa Banjar Kuala (BBK) dan bahasa Banjar Hulu (BBH). Dialek Bahasa Banjar Kuala umumnya dipakai oleh penduduk asli sekitar kota Banjarmasin, Martapura, dan Pelaihari. Dialek Banjar Hulu dipakai oleh penduduk di daerah hulu sungai umumnya daerah Kabupaten Tapin, Hulu Sungai Selatan (Kandangan), Hulu Sungai Tengah (Barabai), Hulu Sungai Utara (Amuntai), dan Tabalong. Selain itu adanya pengaruh budaya Dayak juga ditunjukkan dalam penggunaan kata Indu Diyang yang dalam bahasa Dayak berarti anak kesayangan. Etnik Banjar umumnya memang hidup berdampingan dengan etnik Dayak yang merupakan suku asli pulau Kalimantan, sedangkan etnik Banjar sendiri merupakan etnik yang berasal dari rumpun Melayu.

Etnik Banjar mayoritas tinggal di daerah Kalimantan Selatan, yang merupakan daerah yang dikenal dengan istilah seribu sungai. Daerah ini banyak memiliki anak sungai hingga menjadi tujuan perdagangan dari pedagang-pedagang luar pulau Kalimantan. Seperti diketahui, alur perdagangan tempo dulu dilakukan di daerah-daerah pesisir sungai. Selain untuk berdagang tentu saja terjadi proses adaptasi budaya dan kepercayaan antara pedagang pendatang dengan masyarakat yang ada di Kalimantan Selatan sehingga membentuk sebuah budaya baru yang berujung pada adanya kekhasan budaya etnik Banjar. Dari segi kepercayaan, etnik Banjar merupakan penganut agama Islam sedangkan etnik Dayak umumnya masih menganut kepercayaan leluhur (animisme 
dan dinamisme) atau disebut juga kaharingan. Adapun etnik Dayak yang dapat dijumpai di daerah Kalimantan Selatan bermukim di daerah pegunungan meratus seperti Loksado (Kabupaten Hulu Sungai Selatan), dan Halong (Kabupaten Balangan).

Sastra lisan bentuk dindang dari segi perkembangannya tidak sepesat sastra modern. Peran penting dindang sebagai media penyampai nilai-nilai luhur kehidupan, media komunikasi sosial untuk menyampaikan ajaran, nasihat, dan perekat hubungan pertemanan seakan tidak disadari oleh masyarakat etnik Banjar saat ini (Hasuna \& Bahasa, 2018). Ketidaksadaran dalam melestarikan sastra lisan khususnya dindang membuat dindang semakin tersisih di antara banyaknya jenis nyanyian modern saat ini. Sebagai langkah yang dipandang efektif untuk melestarikan dindang yakni lewat penelitian ilmiah, dalam penelitian ini dikemukakan rumusan masalah sebagai berikut:

1) Bagaimana konteks penuturan dindang anak Unggat-Unggat Apung tersebut?

2) Apa saja wujud ekologi flora, ekologi fauna dan ekologi budaya yang tertuang dalam dindang anak UnggatUnggat Apung?

\section{Konteks Penuturan}

Yang dimaksud konteks penuturan dalam penelitian ini adalah mengenai situasi yang berkenaan dengan peristiwa komunikasi antara penutur dan penerima tuturan, atau yang dimaksud dengan interaksi antarkeduanya. Peran konteks dalam kajian tradisi lisan sangatlah penting (Sibarani, 2012). Sebuah teks sastra lisan akan berbeda makna, maksud, dan fungsinya tergantung pada perbedaan konteksnya. Dalam ragam tradisi lisan ada empat konteks yang harus diperhatikan yaitu: (1) konteks budaya, (2) konteks sosial, (3) kontek situasi, dan (4) konteks ideologi.

(1) Konteks budaya dapat diamati dari tujuan budaya yang dihadirkan dalam teks. Konteks budaya yang berbeda akan menghadirkan ragam budaya yang berbeda. Misal nyanyian yang dinyanyikan pada saat menidurkan anak akan berbeda dengan nyanyian dalam permainan anak.
(2) Konteks sosial berhubungan dengan gambaran siapa saja yang terlibat dalam penuturan teks yang dituturkan.

(3) Konteks situasi mengacu pada waktu, tempat, dan cara penggunaan teks. Waktu berkaitan dengan pembagian waktu dalam sehari, minggu, bulan, tahun, atau musim (siklus pertanian). Konteks situasi berhubungan dengan suasana senang, sedih, mistis, dan suasana lainnya. Konteks tempat mengacu pada lokasi teks tersebut dituturkan. Bahkan juga posisi keberadaan penutur dan khalayaknya. Lokasi pelaksanaan atau pertunjukkan tradisi lisan meliputi bentuk pentas, tempat permainan, dan penonton, permanen atau berpindahpindah, dan sebagainya (Sibarani, 2012).

(4) Konteks ideologi mengacu pada kekuatan apa yang melatarbelakangi penuturan teks, bagaimana pola pikir masyarakat terhadap penuturan suatu teks. Sibarani mengemukakan pendapat bahwa ideologi tercipta karena adanya pengaruh kekuasaan terhadap sejarah, politik, sistem masyarakat, nilai sastra, dan nilai budaya yang membentuk suatu konsep menjadi kebenaran yang wajar (Sibarani, 2012).

\section{Wujud Ekologi dalam Sastra}

Kajian ekologi terhadap sastra yang mulai dikembangkan oleh para peneliti sastra yakni pengkajian sastra yang dikaitkan dengan ekologi, yakni yang erat kaitannya dengan disiplin ilmu biologi yang mengkaji keberlangsungan suatu ekosistem makhluk hidup di alam sekitarnya. Istilah ekologi kemudian disandingkan dengan kajian sastra lingkungan yang dikenal sebagai ekokritik (ekologi dan sastra). Ekologi dan sastra memang dua hal yang berbeda, tetapi memiliki ketergantungan karena sastra berada dalam ekosistem yang mencerminkan kondisi ekologi suatu etnik. Ekologi sastra adalah sebuah cara pandang memahami persoalan lingkungan hidup dalam perspektif sastra. Atau sebaliknya, hal demikian menegaskan bahwa hadirnya sebuah karya sastra tidak terlepas dari unsur lingkungan yang menjadi bagian dari proses dan inspirasi penciptaan karya sastra (Endraswara, 2016).

Kajian ekologi sastra (Rafiek, 2017) adalah kajian yang berupaya membuka 
jalan hubungan antara teori ekologi dengan teori sastra. Kajian ekologi sastra tidak sekedar menganalisis dan membahas kaitan lingkungan dengan karya sastra, tapi lebih dari itu, lingkungan dikritisi dari segi pemeliharaan dan pelestariannya oleh manusia di dalam sebuah karya sastra.

Ekologi sastra adalah ilmu pengetahuan antara organisme dengan lingkungannya (McNaughton, S.J. dan Wolf, 1989). Selain itu, Krebs (Leksono, 2007) mengungkapkan bahwa kajian sastra dengan model pendekatan ekologi akan menjelaskan hubungan antara makhluk hidup dengan lingkungan melalui tiga pendekatan. Pertama, pendekatan deskriptif untuk menjelaskan ekologi berdasarkan faktor ilmiah (kebiasaan, perilaku, dan interaksi-interaksi antarorganisme dan dikaitkan dengan kumpulan vegetasi di bumi). Kedua, pendekatan fungsional menjelaskan ekologi yang ditekankan pada hubungan sebab akibat dengan menganalisis permasalahan umum yang biasa terdapat pada ekosistem berbeda. Yang ketiga, pendekatan evolusi menjelaskan organisme dan hubungan timbal baliknya sebagai produk sejarah evolusi untuk menganalisis sebab-sebab unsur ekologi ada dalam karya sastra.

Ekologi sastra adalah sebuah cara pandang memahami persoalan lingkungan hidup dalam perspektif sastra. Atau sebaliknya, bagaimana memahami kesastraan dalam perspektif lingkungan hidup. Ekologi sastra mempelajari bagaimana manusia beradaptasi dengan lingkungan alamnya. Itulah sebabnya kajian ekologi sastra berupaya menemukan spesifikasi yang lebih tepat mengenai hubungan antara kegiatan manusia dan proses alam tertentu dalam suatu ekosistem yang saling bergantung sebagai suatu komunitas alam. Dengan kajian ekologi sastra akan dapat mengungkap bagaimana peran sastra dalam memanusiakan lingkungannya (Endraswara, 2016).

Sastra lisan seringkali menjadi saksi bahwa lingkungan sangat kondusif bagi kehidupan manusia. Banyak sastra lisan yang mengungkapkan betapa berlimpahnya sumber daya alam yang dimiliki oleh suatu wilayah, kesuburan tahan yang dicerminkan dari beragamnya varietas flora yang tumbuh, beragam jenis fauna yang hidup dan dapat dengan mudah dijumpai di suatu wilayah, atau pun keadaaan sistem budaya yang mencerminkan pola perilaku individu dalam kelompok di suatu wilayah. Mansur (Endraswara, 2016) memberikan gambaran bahwa penelitian sastra dengan meneliti ekologi sastra, tentu permasalahan penelitian akan digiring ke arah hubungan sastra, manusia, dan lingkungannya.

\section{METODE PENELITIAN}

Metode yang digunakan dalam penelitian ini adalah jenis penelitian kualitatif deskriptif yang memfokuskan analisis pada data- data empiris. Dalam menganalisis data, dilakukan analisis penelitian lapangan, yaitu menggunakan lingkungan alamiah sebagai sumber data langsung. Sumber data penelitian ini adalah dindang anak "Unggat-Unggat Apung etnik Banjar Kalimantan Selatan. Untuk mendapatkan data yang akurat digunakan teknik pengumpulan data berupa teknik observasi, wawancara, triangulasi, dan pencatatan lapangan (Sugiono, 2011). Teknik tersebut digunakan untuk menggali konteks penuturan dan wujud ekologi yang terdapat dalam dindang anak UnggatUnggat Apung etnik Banjar Kalimantan Selatan. Pendekatan ekologi sastra akan diterapkan dalam analisis data terkait ekologi flora, fauna, dan budaya. dalam dindang anak Unggat-Unggat Apung etnik Banjar Kalimantan Selatan.

\section{HASIL DAN PEMBAHASAN}

Berikut adalah naskah dindang anak Unggat-Unggat Apung.

Tabel 1: Dindang Anak Unggat-Unggat Apung

\begin{tabular}{lll}
\hline \multicolumn{1}{c}{ Teks asli } & Terjemahan & Larik \\
\hline $\begin{array}{l}\text { Unggat-unggat } \\
\text { apung }\end{array}$ & $\begin{array}{l}\text { Diangkat- } \\
\text { angkat } \\
\text { dilambung }\end{array}$ & 1 \\
\hline $\begin{array}{l}\text { Apung sinali- } \\
\text { nali }\end{array}$ & $\begin{array}{l}\text { Dilambung } \\
\text { tinggi-tinggi }\end{array}$ & 2 \\
\hline
\end{tabular}


Norvia: Analisis Konteks dan Wujud Ekologi Dindang Anak Unggat-Unggat Apung...

\begin{tabular}{|c|c|c|}
\hline $\begin{array}{l}\text { Talipat daun } \\
\text { bakung }\end{array}$ & $\begin{array}{l}\text { Terlipat daun } \\
\text { bakung }\end{array}$ & 3 \\
\hline $\begin{array}{l}\text { Anak punai } \\
\text { rajawi }\end{array}$ & $\begin{array}{l}\text { Anak burung } \\
\text { punai burung } \\
\text { rajawali }\end{array}$ & 4 \\
\hline $\begin{array}{l}\text { Injam kapak } \\
\text { injam balayung }\end{array}$ & $\begin{array}{l}\text { Meminjam } \\
\text { kapak } \\
\text { meminjam } \\
\text { balayung }\end{array}$ & 5 \\
\hline $\begin{array}{l}\text { Sagan napa } \\
\text { balayung? }\end{array}$ & $\begin{array}{l}\text { Untuk apa } \\
\text { balayung? }\end{array}$ & 6 \\
\hline $\begin{array}{l}\text { Manabang kayu } \\
\text { tinggi }\end{array}$ & $\begin{array}{l}\text { Menebang kayu } \\
\text { yang tinggi }\end{array}$ & 7 \\
\hline $\begin{array}{l}\text { Hagan napa } \\
\text { kayu tinggi? }\end{array}$ & $\begin{array}{l}\text { Buat apa kayu } \\
\text { yang tinggi? }\end{array}$ & 8 \\
\hline Maulah titian & $\begin{array}{l}\text { Membuat } \\
\text { jembatan }\end{array}$ & 9 \\
\hline $\begin{array}{l}\text { Gasan napa } \\
\text { titian? }\end{array}$ & $\begin{array}{l}\text { Untuk apa } \\
\text { jembatan? }\end{array}$ & 10 \\
\hline $\begin{array}{l}\text { Maambili } \\
\text { hayam } \\
\text { tungkung }\end{array}$ & $\begin{array}{l}\text { Mengambil } \\
\text { ayam yang } \\
\text { ekornya pendek }\end{array}$ & 11 \\
\hline $\begin{array}{l}\text { Sagan napa } \\
\text { hayam } \\
\text { tungkung? }\end{array}$ & $\begin{array}{l}\text { Buat apa ayam } \\
\text { yang ekornya } \\
\text { pendek }\end{array}$ & 12 \\
\hline $\begin{array}{l}\text { Maubati indu } \\
\text { diyang }\end{array}$ & $\begin{array}{l}\text { Membuat obat } \\
\text { untuk Indu } \\
\text { Diyang }\end{array}$ & 13 \\
\hline $\begin{array}{l}\text { Kanapa Indu } \\
\text { diyang? }\end{array}$ & $\begin{array}{l}\text { Kenapa Indu } \\
\text { diyang? }\end{array}$ & 14 \\
\hline $\begin{array}{l}\text { Kana puting } \\
\text { balayung }\end{array}$ & $\begin{array}{l}\text { Kena ujung } \\
\text { balayung }\end{array}$ & 15 \\
\hline $\begin{array}{l}\text { Dimana } \\
\text { kananya? }\end{array}$ & $\begin{array}{l}\text { Di mana } \\
\text { kenanya? }\end{array}$ & 16 \\
\hline $\begin{array}{l}\text { Di intang } \\
\text { hidung }\end{array}$ & Di dekat hidung & 17 \\
\hline $\begin{array}{l}\text { Saapa } \\
\text { darahnya? }\end{array}$ & $\begin{array}{l}\text { Seberapa } \\
\text { darahnya? }\end{array}$ & 18 \\
\hline $\begin{array}{l}\text { Sagantang } \\
\text { bajubung }\end{array}$ & $\begin{array}{l}\text { Segantang } \\
\text { penuh }\end{array}$ & 19 \\
\hline $\begin{array}{l}\text { Nangapa } \\
\text { kasainya? }\end{array}$ & $\begin{array}{l}\text { Apa yang jadi } \\
\text { obatnya? }\end{array}$ & 20 \\
\hline $\begin{array}{l}\text { Gula lawan } \\
\text { galapung }\end{array}$ & $\begin{array}{l}\text { Gula dan } \\
\text { tepung }\end{array}$ & 21 \\
\hline $\begin{array}{l}\text { Dimana } \\
\text { mangukut? }\end{array}$ & $\begin{array}{l}\text { Dimana } \\
\text { mengambil? }\end{array}$ & 22 \\
\hline Di dada lasung & $\begin{array}{l}\text { Di dalam } \\
\text { lesung }\end{array}$ & 23 \\
\hline Naik ka rumah? & Naik ke rumah & 24 \\
\hline $\begin{array}{l}\text { Mahirup } \\
\text { gangan } \\
\text { kangkung }\end{array}$ & $\begin{array}{l}\text { Menghirup } \\
\text { kuah kangkung }\end{array}$ & 25 \\
\hline
\end{tabular}

\begin{tabular}{lll}
\hline Turun katanah? & Turun ke tanah & 26 \\
\hline $\begin{array}{l}\text { Tajajak tahi } \\
\text { mantung }\end{array}$ & $\begin{array}{l}\text { Keinjak tahi } \\
\text { ayam }\end{array}$ & 27 \\
\hline $\begin{array}{l}\text { Turun ka } \\
\text { batang? }\end{array}$ & $\begin{array}{l}\text { Turun ke } \\
\text { sungai? }\end{array}$ & 28 \\
\hline $\begin{array}{l}\text { Mananjak } \\
\text { jukung }\end{array}$ & $\begin{array}{l}\text { Membawa } \\
\text { perahu yang }\end{array}$ & 29 \\
\hline $\begin{array}{l}\text { Tulak ka } \\
\text { subarang? }\end{array}$ & $\begin{array}{l}\text { sompak } \\
\text { Salak Kuyuk }\end{array}$ & $\begin{array}{l}\text { Pergi ke } \\
\text { sebarang }\end{array}$ \\
$\begin{array}{l}\text { Caung-caung gonggong } \\
\text { Uk...uk... }\end{array}$ & $\begin{array}{l}\text { anjing } \\
\text { Galak }\end{array}$ \\
& $\begin{array}{l}\text { Uk uk } \\
\text { (peniruan bunyi }\end{array}$ \\
& angjing) & \\
&
\end{tabular}

Dindang anak Unggat-Unggat Apung terdiri atas 31 larik. Terdapat persamaan bunyi atau rima a-b-a-b pada larik ke-1, 2, 3 dan 4, a-a pada larik ke 5 sampai larik ke 31. Berbeda dengan pantun yang memiliki sampiran dan isi dalam setiap baitnya, pada dindang semua larik berupa isi yang hampir sama dengan ciri syair yakni setiap lariknya saling membentuk satu kesatuan isi yang sama. Syair lebih mengutamakan kata-kata yang indah dan seringkali menggunakan kalimat pembuka dan penutup yang mengandung makna yang religius. Misal larik pembuka pada syair "Bermula salam dengan bismillah...". Sedangkan dindang atau nyanyian UnggatUnggat Apung dalam penggunaan kata setiap larik hanya memperhatikan persamaan bunyi agar dindang menarik untuk dinyanyikan. Dindang UnggatUnggat Apung berdasarkan isi lariknya terdiri atas dua jenis larik yakni larik yang berisi pertanyaan dan larik yang berisi jawaban dari pertanyaan pada larik sebelumnya.

Menurut informan Saniah (50 tahun), dindang Unggat-Unggat Apung berisi nyanyian yang bercerita tentang seorang Indu Diyang (Indu dalam bahasa Dayak berarti anak, sedangkan Diyang bermakna kesayangan). Dindang ini menceritakan seorang anak kesayangan yang terluka di bagian hidungnya akibat terkena ujung balayung yakni alat yang digunakan untuk menebang pohon yang berdiameter besar dan batangnya tinggi (kayu tinggi), pohon 
tesebut umumnya digunakan untuk bangunan rumah, atau titian (jembatan) seperti yang disebutkan dalam larik dindang ke 8 dan 9. Pada larik selanjutnya dijelaskan cara untuk mendapatkan obat agar luka Indu diyang dapat sembuh. Dindang ini menyebutkan obat tradisional yang digunakan untuk mengobati Indu diyang seperti hayam tungkung (ayam yang berekor pendek), gula, galapung (tepung). Setelah diobati Indu Diyang pun bisa menyantap makanan, bermain di tanah, ke sungai, sampai pergi ke seberang kemudian bertemu dengan kuyuk (anjing) yang mengonggong.

Informan juga menjelaskan bahwa larik dalam dindang Unggat-Unggat Apung merupakan perpaduan bahasa Banjar dengan bahasa Dayak, seperti penggunaan kosakata dalam bahasa Dayak yakni dalam larik menyebut kata balayung yang merupakan alat untuk menebang pohon khas suku Dayak, dan Indu diyang panggilan untuk anak kesayangan. Sejak dahulu etnik Banjar dan Dayak merupakan suku asli dari pulau Kalimantan khususnya daerah Kalimantan Selatan, hal itu pula yang menjadi faktor pembauran penggunaan kosakata dalam sastra lisan yang berkembang di masyarakat Kalimantan Selatan.

\section{Analisis Konteks Penuturan}

Analisis konteks penuturan dindang anak Unggat-Unggat Apung etnik Banjar Kalimantan Selatan yakni meliputi:

1) Konteks Situasi

a. Penutur, yakni orang yang menyanyikan dindang anak UnggatUnggat Apung umumnya adalah orang dewasa atau orang tua. Mereka memiliki kemampuan untuk mengangkat beban dengan menggunakan kaki. Dari segi penutur dindang ini tidak ada kekhususan jenis kelamin, baik laki- laki atau perempuan boleh saja menyanyikan dindang ini. Hanya saja sebagian besar yang menjadi penutur dindang UnggatUnggat Apung adalah perempuan.

b. Waktu, dindang Unggat-Unggat Apung seringkali dinyanyikan sekaligus dijadikan permainan bersama saat kumpul dengan keluarga. Namun saat ini permainan ini sudah jarang dilakukan oleh etnik Banjar karena tidak lagi familiar dengan kehidupan masyarakat.

c. Tujuan, dindang Unggat-Unggat Apung bertujuan sebagai nyanyian pengiring permainan tradisional etnik Banjar yang fungsinya menghibur anakanak.

d. Peralatan, dalam melantunkan dindang Unggat-Unggat Apung tidak menggunakan alat musik apapun. Namun nyanyian ini dilantunkan hanya saat permainan unggat apung dilakukan. Dalam permainan pun tidak menggunakan alat hanya menggunakan anggota tubuh yakni kaki untuk mengangkat tubuh anak.

e. Peserta, karena dalam melantunkan dindang ada permainan yang dilakukan maka tentu terdapat si pemain unggat apung, yang menjadi si pengunggat yakni satu orang dewasa dan si apung (yang di angkat) bisa satu atau dua orang sekaligus anak usia $1-5$ tahun. Yang namanya permainan tentu mendatangkan kesenangan. Hal ini pula yang terjadi dalam permainan UnggatUnggat Apung yakni ketika si anak akan tertawa dan merasa senang ketika badannya terangkat ke atas (diapung). Dalam permainan ini tidak ada istilah menang atau kalah karena permainan ini hanya bertujuan untuk mengisi waktu bermain etnik Banjar dengan keluarga.

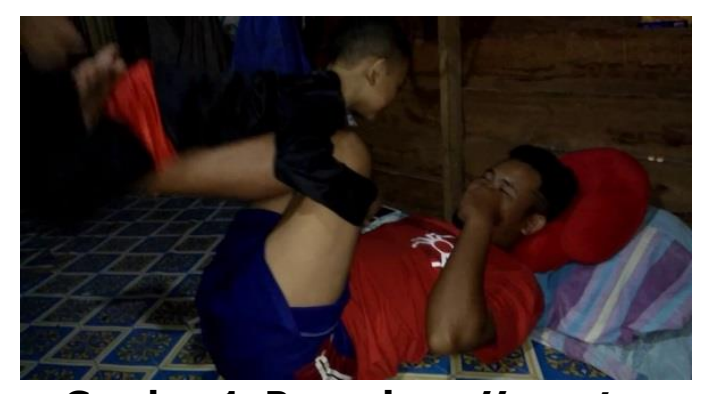

Gambar 1. Permainan Unggat Apung

\section{Sumber:}

https://www.youtube.com/watch?v=g Ax0GXu4rnA

2) Konteks Sosial

Dindang anak Unggat-Unggat Apung yang dinyanyikan bersamaan dengan permainan unggat apung secara konteks sosial telah menjadi bagian dari 
permainan tradisional etnik Banjar yang menghibur. Hiburan yang dapat membangun keharmonisan keluarga antara orangtua dan anak secara sederhana. Pewarisan secara turun temurun juga tanpa sengaja dilakukan dalam hal melantunkan dindang dan permainan yang dilakukan dari generasi ke generasi.

3) Konteks Budaya

Adanya dindang anak Unggat-Unggat Apung bagi etnik Banjar tentu menjadi bagian dari kebiasaan yang membentuk suatu budaya berciri khas etnik Banjar. Dindang yang menggunakan kosakata berbahasa Banjar dan juga menggambarkan ekologi etnik Banjar adalah kekayaan budaya yang patut dilestarikan sekaligus bukti sejarah keberadaan suatu ekologi baik flora, fauna dan budaya.

Dindang anak Unggat-Unggat Apung memang bukan nyanyian yang ekslusif yang hanya dapat dilantunkan saat upacara adat yang bersifat sakral. Semua orang diperbolehkan untuk menyanyikan dindang ini dan tidak perlu tempat atau waktu khusus. Namun saat ini hampir sebagian besar generasi muda etnik Banjar tidak hafal bahkan tidak mengenal lirik dindang anak Unggat-Unggat Apung. Hal demikian dilatarbelakangi sudah hampir punahnya permainan unggat apung di kalangan anak-anak, dan para orang tua etnik Banjar yang sudah meninggalkan kebiasaan bermain unggat apung dalam rutinitas berkumpul dengan keluarga. Dari hasil wawancara terhadap informan (Saniah 50 tahun) sebagai penutur dindang menerangkan bahwa penutur memperoleh teks dindang anak Unggat-Unggat Apung dengan cara menghafal dan mengingat tuturan dari penutur sebelumnya yang merupakan orang tua beliau yang juga merupakan pendengar dari penutur sebelumnya. Begitu seterusnya dilakukan turuntemurun dari nenek moyang beliau.

\section{Analisis Wujud Ekologi Flora, Fauna, dan Budaya dalam dindang anak Unggat-Unggat Apung}

Analisis terkait ekologi etnik Banjar yang tertuang dalam dindang anak UnggatUnggat Apung meliputi unsur ekologi flora, unsur ekologi fauna, dan unsur ekologi dalam konteks budaya yang terkait peralatan dan perlengkapan hidup etnik Banjar. Unsur ekologi flora meliputi ekosistem tumbuhan yang terdapat dalam larik dindang Unggat-Unggat Apung yang dijelaskan sebagaimana berikut:

\section{Bakung (Bunga Bakung)}

Bakung (Crinum asiaticum) termasuk sayuran organik, yaitu sayuran yang hidup dan berkembang di alam bukan hasil budi daya. Bakung tumbuh liar (makrofita) di pinggiran atau dataran sungai atau danau. Tanaman bakung pada umumnya berdaun hijau cerah dengan ukuran yang besar dan lebar serta mempunyai bunga yang berwarna putih bersih. Bagian dari tanaman bakung yang dikonsumsi adalah bagian batangnya. Bakung memiliki kandungan kimia seperti Likorina, Krinidina, Hemantamina, dan Krinamina yang berfungsi sebagai analgesik, namun kandungan zat kimia yang terdapat di dalamnya dapat menjadi racun yang berbahaya bagi tubuh jika dimasak tanpa membuang bagian warna merah yang terdapat antara batang daun dan batang muda. Bakung biasanya diolah sayur berkuah atau ditumis.

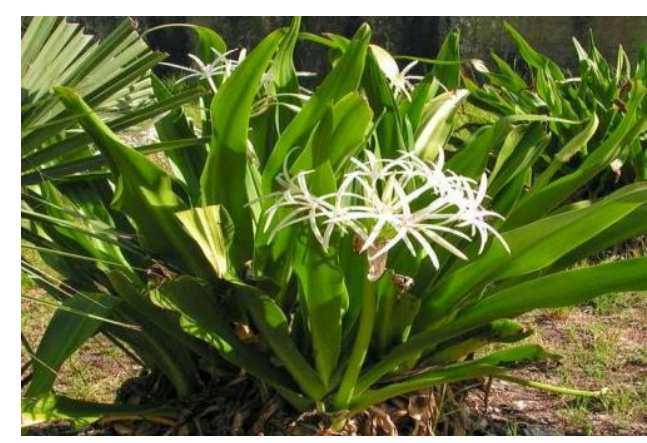

Gambar 2. Bakung

Sumber: https://manfaat.co.id/manfaatdaun-bakung 
Larik ke-3 pada dindang anak UnggatUnggat Apung menyebutkan bagian dari tanaman bakung yaitu daun. Daun bakung jika disentuh akan terasa dingin di permukaan daunnya. Seseorang yang sakit ketika disentuh maka badannya dingin diibaratkan seperti bakung, atau keadaan ketika seseorang kaget sehingga wajahnya pucat dan tangannya dingin saat disentuh. Begitu pula kondisi anak yang sedang diangkat dan dilambung akan menyebabkan badannya dingin karena takut ketinggian. Namun ketakutan tersebut hanya sesaat dirasakan anak. Lama-kelamaan si anak akan menikmati seiring lantunan dindang yang dinyanyikan.

\section{Kayu tinggi (Pohon Kayu)}

Pada larik ke-8 terdapat kata kayu tinggi yang menandakan adanya pohon yang tinggi yang dapat dijadikan titian (jembatan) seperti yang tertuang pada larik ke-10. Lingkungan etnik Banjar yang akrab dengan hutan dan sungai membuat etnik Banjar seringkali menuangkannya dalam karya sastra baik lisan maupun tulisan. Jika menilik ke daerah pedalaman Kalimantan masih banyak dijumpai titian dari batang kayu Ulin yang tetap kokoh hingga puluhan tahun yang memberikan akses untuk menghubungkan dari satu kampung ke kampung lainnya.

Ulin atau disebut juga dengan bulian atau kayu besi adalah pohon berkayu dan merupakan tanaman khas Kalimantan. Ulin adalah jenis pohon asli Indonesia yang digolongkan ke dalam suku Lauraceae. Ulin memiliki tinggi pohon umumnya $30,35 \mathrm{~m}$, diameter setinggi dada $60-120 \mathrm{~cm}$.

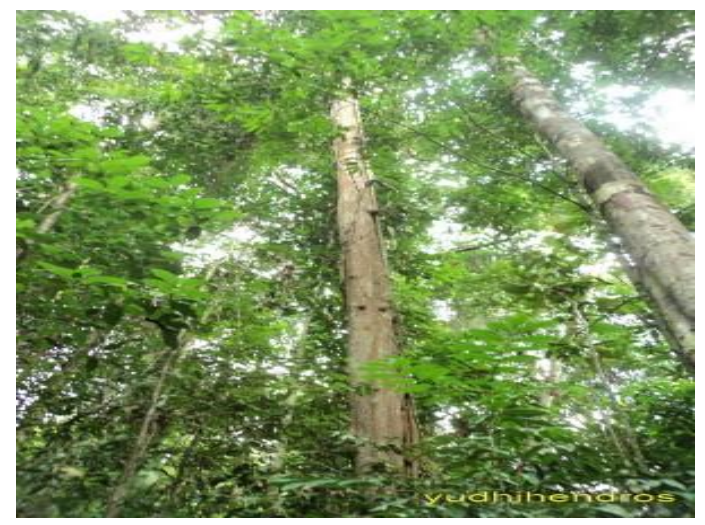

Gambar 3. Pohon Kayu Ulin
Sumber:https://www.kompasiana.com /image/yudhihendros/5518a6 6f813311a2689deab1/kayuulin-sang-primadona-yangterancam-punah

\section{Kangkung}

Kangkung adalah tumbuhan yang termasuk jenis sayur-sayuran dan ditanam sebagai makanan. Kangkung banyak dijual di pasar-pasar. Kangkung banyak terdapat di kawasan Asia dan merupakan tumbuhan yang dapat dijumpai hampir di mana-mana terutama di kawasan berair. Wikipedia

Larik ke-26 menyebutkan gangan kangkung adalah sayuran kangkung yang dimasak berkuah. Tanaman kangkung umumnya memang dapat hidup subur di daerah dataran rendah. Kangkung liar yang hidup di air biasanya memiliki warna batang merah kecoklatan dan lebih keras dibanding dengan kangkung budidaya.

Etnik Banjar biasanya menggangan kangkung (memasak dengan memberi kuah) disertai dengan sayuran kaladi (talas), tungkul (jantung pisang), dan susupan (sejenis tanaman putri malu namun tidak berduri. Masakan ini biasa disebut juga gangan karuh (karna warna kuah yang keruh akibat pencampuran sayuran dan bumbu-bumbu) dan tentunya masakan ini sangat dinikmati oleh etnik Banjar.

\section{Sumber:}

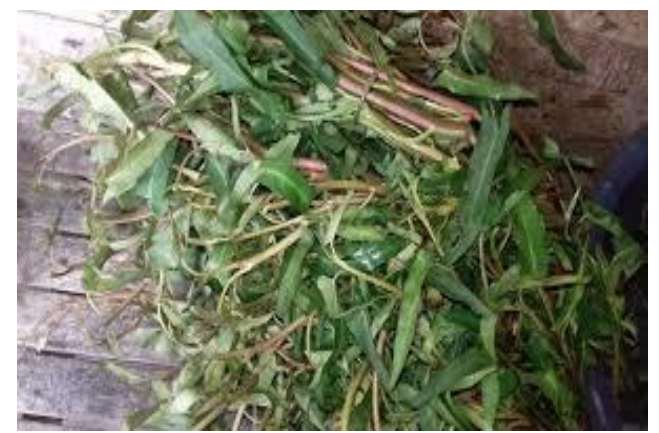

Gambar 4. Kangkung

https://steemit.com/esteem/@nyakti/kang kung-liar-alami-dan-sehat-25fec7539492a

Ekologi fauna etnik Banjar juga tertuang dalam dindang anak Unggat-Unggat Apung. Keberadaan ekosistem hewan atau binatang di suatu wilayah dapat menjadi tolok ukur kondisi wilayah tersebut. 
Beragam jenis fauna yang hidup di daerah tempat tinggal etnik Banjar menjadi gambaran keasrian alamnya. Berikut beberapa jenis fauna yang tertuang dalam dindang anak Unggat-Unggat Apung yaitu,

\section{Punai dan Rajawali}

Pada larik ke-4 disebutkan anak punai rajawali. Punai adalah genus burung berukuran sedang hingga besar yang tergolong famili Columbidae dan bersaudara dekat dengan merpati. Punai termasuk burung arboreal yang beraktivitas di atas pohon dan memakan buah-buahan. Genus ini terdiri atas 23 spesies. Burung yang merupakan kerabat dari columbidae ini habitatnya berada di hutan yang masih lebat. Aktivitas burung ini biasanya terlihat dalam kelompok antara 2 ekor hingga puluhan ekor. Burung ini juga sering mencari makan di pohon yang mempunyai buah kecil, bersamasama dengan burung pemakan buah yang lainnya. Perbedaannya dari jenis kelamin burung ini bisa diamati pada warnanya yang berbeda. Punai yang berjenis kelamin jantan berwarna lebih indah yang memiliki kombinasi warna yang bermacam-macam. Punai betina biasanya hanya berwarna hijau (https://www.indozone.id/fakta-danmitos/kJsmoV/burung-punai-warna-warnibulunya-yang-indah.)

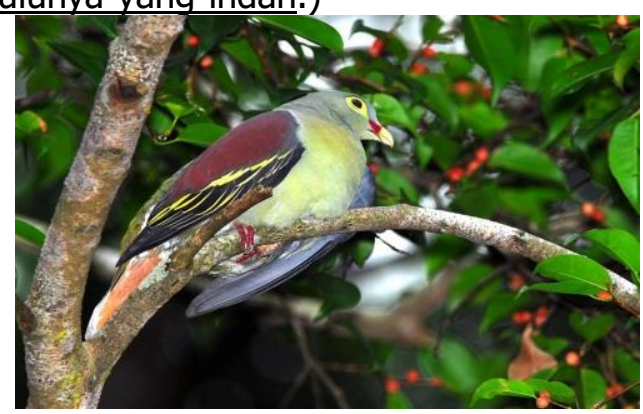

Gambar 5. Burung Punai

Sumber: https://id.wikipedia.org/wiki/Punai

Sementara itu, rajawali adalah jenis burung yang memiliki penglihatan yang sangat baik jika dibandingkan dengan manusia. Hal itu disebabkan jumlah fotoreseptor di retina lebih dari 1.000 .000 per $\mathrm{mm}$ persegi. Burung jenis ini juga memiliki jangka hidup hingga 70 tahun dan pada umur ke-40 terjadi peningkatan pertumbuhan bulu yang terlalu lebat sehingga membuatnya sulit terbang dan ditandai juga dengan paruhnya yang mulai retak. Pada saat itu ia akan bersembunyi di tempat yang tinggi untuk mencabuti bulunnya dan mematuki paruhnya ke batu hingga hancur. Bulu dan paruhnya akan kembali pulih dalam jangka waktu 6 bulan baru kemudian ia dapat mencari makan kembali. Perilaku alamiah inilah yang membedakan burung rajawali dengan burung elang yang seringkali dianggap sama karena kemiripannya.

Dindang anak Unggat-Unggat Apung mengibaratkan si anak sebagai anak burung punai yang cantik dan rajawali yang gagah yang seakan-akan dapat terbang tinggi seperti burung saat diunggat apung (diangkat dan dilambung). Si anak biasanya akan berpegang erat pada betis si ibu atau si bapak yang maunggat apungnya, dan seringkali anak akan tertawa ketika badannya sudah berada di atas.

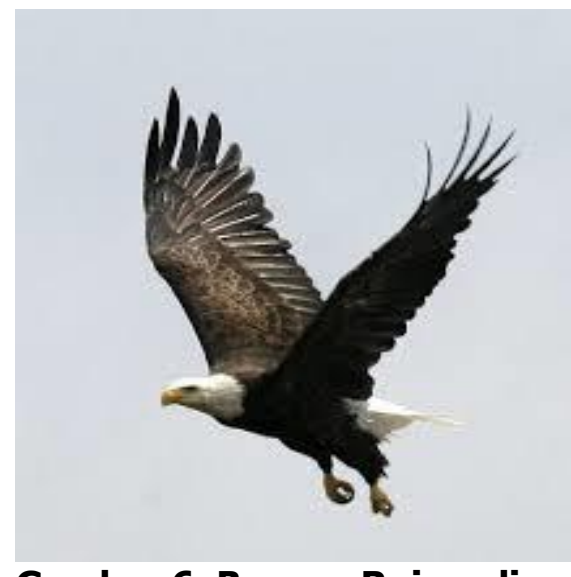

Sumber:

Gambar 6. Burung Rajawali

https://web.facebook.com/pg/RAJAWALI-

PUTIH-KALIMANTAN-BARAT-

183403223168/posts/

\section{Hayam Tungkung (Ayam)}

Pada larik ke-12 disebutkan hayam tungkung (ayam yang berekor pendek), yang merupakan hewan peliharaan yang sering dijadikan ternak di bawah kolong rumah etnik Banjar. Namun jenis hayam tungkung agak sedikit berbeda dari ayam umumnya. Ayam ini hidup liar di hutan. Untuk mendapatkannya harus bersusah payah menangkapnya. Ayam jenis ini biasa dijadikan untuk ritual pengobatan oleh 
etnik Banjar. Seperti yang dijelaskan pada larik ke-14 bahwa ayam ini digunakan untuk mengobati si Indu Diyang yang terkena ujung balayung.

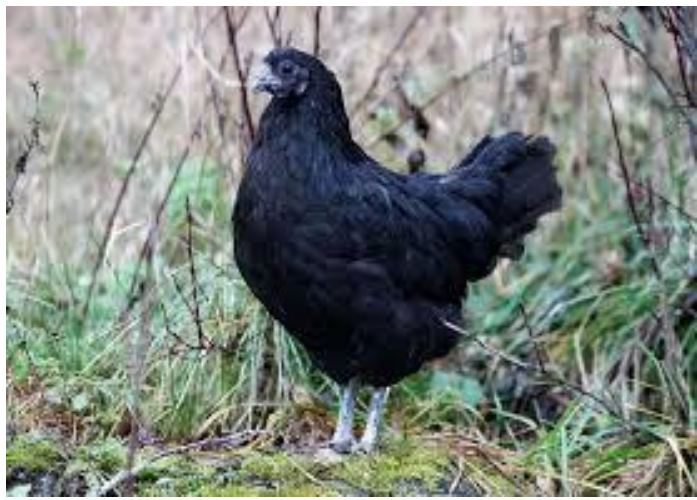

\section{Gambar 7. Hayam Tungkung}

Sumber: wikipidea.org

Pengobatan dengan menggunakan ayam sebagai syarat pengobatan biasa dilakukan oleh para dukun kampung pada jaman dulu. Masih kentalnya kepercayaan akan roh nenek moyang dan perpaduan budaya antara etnik Banjar dan Dayak membuat ritual pengobatan semacam ini juga dikenal oleh etnik Banjar yang mayoritas beragama muslim. Dalam sastra lisan ini diungkapkan bahwa pengobatan menggunakan ayam benar adanya. Daging dan darah ayam biasanya digunakan untuk sesajen dalam ritual pengobatan sehingga ada kemungkinan sastra lisan etnik Banjar terkait dindang anak Unggat-Unggat Apung ini juga mengambil budaya etnik dayak yang memang hidup berdampingan dengan etnik Banjar di daerah Pegunungan Meratus khususnya.

\section{Kuyuk (Anjing)}

Pada larik ke-32 disebutkan salak kuyuk caung-caung, yang berarti anjing yang menggonggong. Kuyuk (anjing) merupakan hewan yang tergolong buas, tetapi sering dipelihara untuk menjadi binatang penjaga kebun atau halaman rumah.

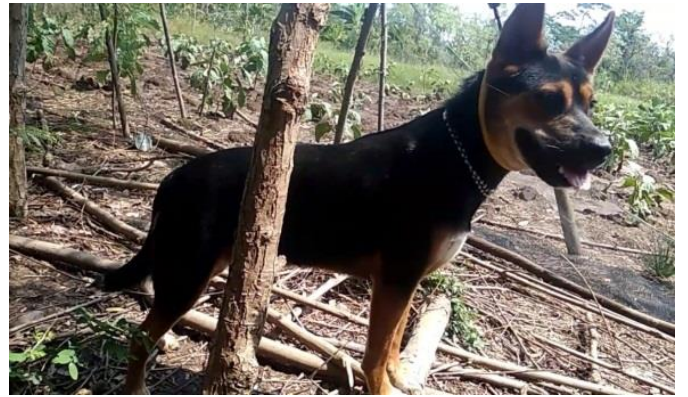

Sumber:

Gambar 8. Kuyuk (Anjing)

https://www.youtube.com/watch?v= hXW $\underline{\text { hibEHPO }}$

Dindang anak Unggat-Unggat Apung memiliki larik penutup salak kuyuk caungcaung uk...uk yang merupakan akhir dari dindang. Pengucapan larik akhir ini dibarengi dengan gerakan mengangkat anak setinggi mungkin dengan betis yang posisinya tegak lurus sehingga si anak akan langsung turun merosot ke perut orang yang maunggat apungnya.

Selain ekologi flora dan fauna, dindang anak Unggat-Unggat Apung juga menyebutkan beberapa peralatan dan perlengkapan hidup etnik Banjar seperti berikut ini.

\section{Kapak}

Kapak adalah alat untuk menebang kayu atau membelah kayu menjadi potongan yang lebih kecil dan hampir sama fungsinya dengan balayung yang digunakan sebagai alat penebang kayu. Tradisi membuka lahan pertanian dengan cara menebang pohon biasa dilakukan oleh etnik Banjar. Hal itu dilakukan terutama untuk membuka lahan pertanian di daerah lahan basah yang biasanya ditumbuhi pohon-pohon galam, atau di daerah pegunungan untuk dijadikan lahan berkebun atau bertani. 


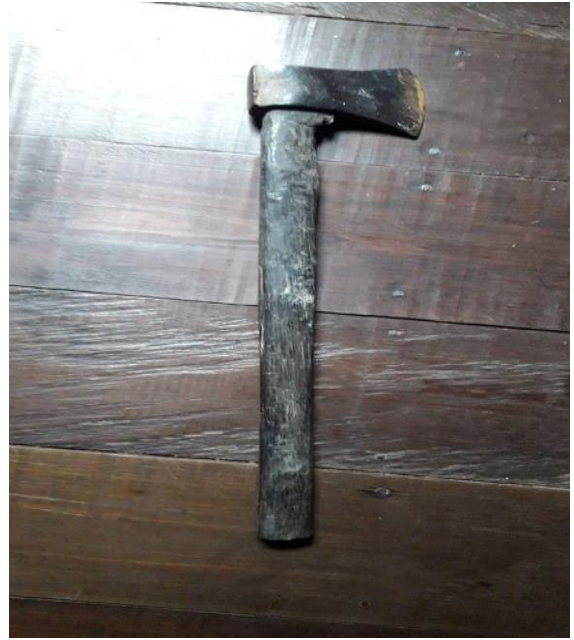

Gambar 9. Kapak

Sumber: Dokumen Pribadi

\section{Balayung}

Balayung adalah alat pertanian atau menebang pohon khas Kalimantan yang berfungsi untuk menebang kayu atau memotong kayu yang keras. Balayung jenis ini sering disebut balayung panatak/pembelah. Sementara balayung parah berfungsi untuk menggali lubang, seperti membuat perahu atau melubangi lesung. Dalam tradisi suku Jawa, alat ini semacam kapak atau wadung. Balayung terbuat dari logam tajam untuk kapaknya dan kayu untuk bagian pegangan atau tangkainya. Sementara kapak dan tangkai dilekatkan dengan ikatan rotan.

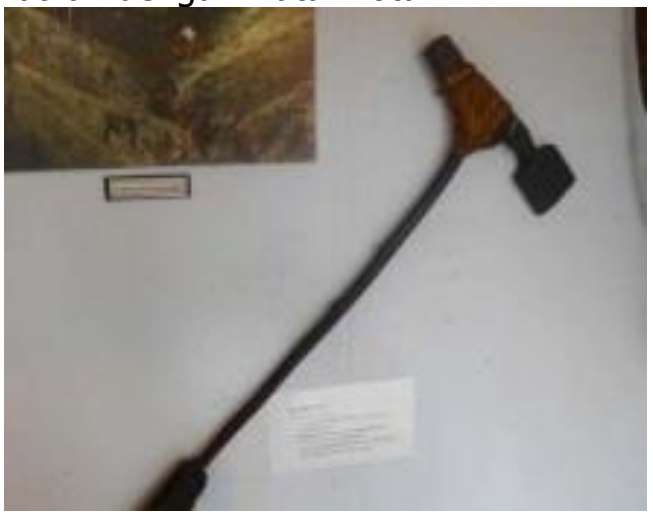

Gambar 10. Balayung

Sumber:

https://wartabisnisindonesia.files.wordpres s.com/2014/08/20140808-2.jpg

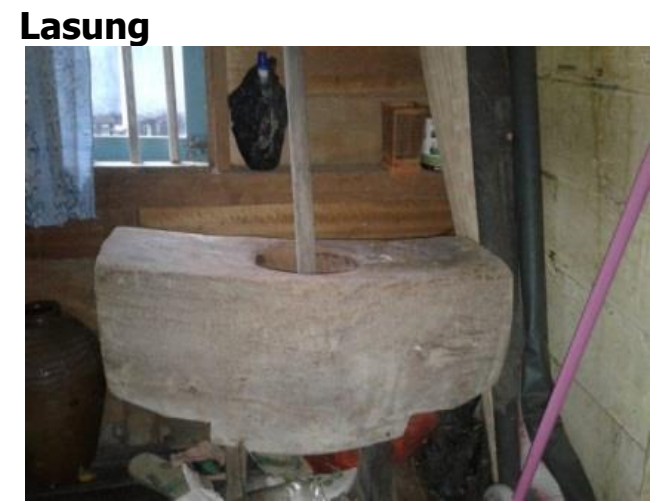

Gambar 11. Lasung (lesung)

Sumber: Dokumen Pribadi

Penggunaan kata lasung pada larik ke-24 dindang anak Unggat-Unggat Apung yang merupakan jawaban larik 23, di dada lasung berarti di bagian tengah lasung yang merupakan bagian untuk menumbuk baik itu padi menjadi beras, beras jadi tepung, atau menumbuk gula untuk dijadikan lebih halus teksturnya. Gula dan tepung juga sering kali dijadikan pelengkap piduduk (sajen) pada acara perkawinan atau ritual pengobatan tradisional. Hal itu dituangkan pada larik 22 bahwa gula dan galapung (tepung) merupakan obat untuk mengobati hidungnya si Indu Diyang yang terluka akibat terkena ujung balayung.

Lasung yang kuat dan tahan lama (awet) dibuat dari batang kayu ulin yang diameternya besar sehingga dapat membuat lobang yang cukup besar pula. Kayu ulin memang terkenal dengan kekuatannya sehingga jaman dahulu jika memiliki lesung dari kayu ulin merupakan hal yang sangat membanggakan dan tidak jarang juga menjadi incaran maling karena harganya yang mahal. Biasanya setiap kali acara bakawinan (pernikahan) atau salamatan (kenduri), etnik Banjar akan membawa lasung dan halu untuk dipinjamkan selama acara sebagai alat perlengkapan dalam membuat hidangan dalam acara tersebut. Orang yang kaya tidak akan meminjam namun membuat atau membeli. 
Norvia: Analisis Konteks dan Wujud Ekologi Dindang Anak Unggat-Unggat Apung...

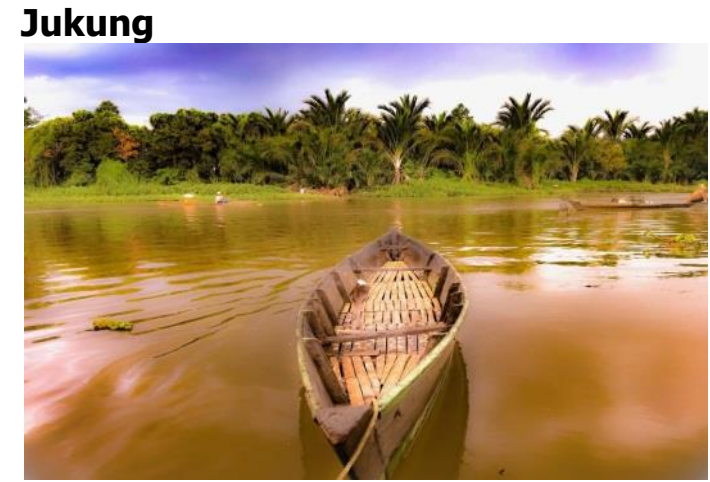

Gambar 12 . Jukung (sampan)

Sumber: Dokumen Pribadi

Jukung (sampan) digunakan sebagai alat transportasi di air oleh etnik Banjar. Jukung digunakan sebagai alat untuk mengangkut orang dengan jumlah terbatas. Biasanya jukung ukuran kecil hanya dapat menampung $2-3$ orang. Harus berhati-hati memilih posisi duduk setiap penumpang karena jukung mudah oleng (balinggang) apalagi jika penumpang duduknya tidak dalam keadaan tenang.

Adapun yang dimaksud dengan jukung umpung pada larik ke-30 adalah jukung atau sampan yang terbuat dari bahan kayu yang bagian ujungnya sudah lapuk kayunya sehingga patah sebagian. Jukung umpung bisa diartikan dengan jukung yang keadaannya sudah rusak sebagian, namun masih dapat digunakan karena hanya bagian kayu atasnya yang patah. Berbeda dengan jukung buntus yang harus ditambal jika ingin digunakan karena dapat menyebabkan jukung karam.

\section{SIMPULAN}

Berdasarkan hasil penelitian dapat disimpulkan bahwa pada larik dindang anak Unggat-Unggat Apung etnik Banjar Kalimantan Selatan memuat unsur ekologi flora, fauna, dan budaya yang tecermin dalam peralatan dan pelengkapan hidup etnik Banjar. Keberadaan sastra lisan sebagai bagian dari tradisi lisan perlu dilestarikan. Keberadaan ekologi flora dan fauna juga merupakan salah satu faktor penting untuk memaknai sebuah sastra lisan. Selain itu unsur budaya yang tertuang dalam tujuh unsur kebudayaan, salah satunya peralatan dan perlengkapan hidup merupakan gambaran adanya keberadaan suatu kebudayaan etnik yang memiliki kekhasan tersendiri.

\section{DAFTAR PUSTAKA}

Adeliani, N. (2015). LAGU MENIDURKAN ANAK PADA MASYARAKAT BANJAR: Kajian Bentuk, Makna, dan Fungsi. A/Banjari: Jurnal IImiah IImu-IImu Keislaman, 13(2), 265-283. https://doi.org/10.18592/albanjari.v13i2.403

Danandjaja, J. (2007). Folklor Indonesia: ilmu gosip, dongeng, dan lain-lain. Pustaka Utama Grafiti.

Endraswara, S. (2016). Metodologi penelitian sastra ekologi konsep langkah dan penerapan). CAPS (Center for Academic Publishing Service).

Hasuna, H. K., \& Bahasa, P. (2018). makna, sastra lisan Banjar, dindang. 3(1), 47-55.

Leksono, A. S. (2007). Ekologi: Pendekatan Deskriptif dan Kuantitatif. Bayumedia Publishing.

Lembah, G. (n.d.). Sastra Lisan Di Kecamatan Dondo Kabupaten Tolitoli ( Kajian Ekokritik ). 118-125.

McNaughton, S.J. dan Wolf, L. L. (1989). Ekologi umum. World Bank Educaation IX Project.

Pudentia. (2008). Metodologi kajian tradisi lisan. Asosiasi Tradisi Lisan.

Rafiek. (2017). Teori sastra, dari kelisanan sampai perfilman. Program Studi Magister Pendidikan Bahasa dan Sastra Indonesia, FKIP, Universitas Lambung Mangkurat dan Pustaka Pelajar.

Salleh, M. H. (1995). Menyurat pada dengung: lipatan lisan pada sastra tertulis. Warta ATL. ATL.

Sibarani, R. (2012). Kearifan Lokal; Hakikat, Peran, dan Metode Tradisi Lisan. 
Norvia: Analisis Konteks dan Wujud Ekologi Dindang Anak Unggat-Unggat Apung...

ATL.

Sudikan, S. Y. (2015). Metode penelitian sastra lisan. CV.Pustaka Ilalang Group.

Sugiono. (2011). Metode Penelitian Kombinasi (Mixed Method). Alfabeta.

Tawaulu, A. K. (2017). Analisis Konteks dan Proses Penciptaan Nyanyian Lusi Negeri Dulak Kecamatan Pulau Gorom Kabupaten Seram Bagian Timur. Riksa Bahasa, 3, 32-44. 